\title{
Should Elective Surgical Procedures Be Delayed in Pediatric Cases in Covid-19 Pandemic? Until When? Is PCR Required in The Preoperative Period?
}

\author{
Covid-19 Pandemisinde Çocuklarda Elektif Cerrahi İşlemler \\ Ertelenmeli mi? Ne Zamana Kadar? Preoperatif Dönemde PCR \\ Gerekli midir?
}

\author{
Elif Emel ERTEN ${ }^{1}$, Can Ihsan OZTORUN² Ahmet ERTURK¹, Sabri DEMIR', Dogus GUNEY², \\ Gulsum Iclal BAYHAN ${ }^{3}$, Suleyman Arif BOSTANCl ${ }^{1}$, Hayal DORUK ${ }^{1}$, Gulsen KESKIN ${ }^{4}$, \\ Sarper MUFTUOGULLARI ${ }^{1}$, Mujdem Nur AZILI², Emrah SENEL ${ }^{2}$
}

${ }^{1}$ Ankara City Hospital, Department of Pediatric Surgery, Ankara,Turkey

${ }^{2}$ Ankara Yıldırım Beyazıt University Faculty of Medicine Department of Pediatric Surgery, Ankara, Turkey

${ }^{3}$ Ankara Yıldırım Beyazıt University Faculty of Medicine. Department of Pediatric Infections, Ankara, Turkey

${ }^{4}$ Ankara City Hospital, Department of Pediatric Anesthesiology, Ankara, Turkey

\begin{abstract}
Objective: The COVID-19 pandemic has led to major changes in healthcare around the world, including postponing elective surgery. The aim of this study is to examine the COVID-19 test results in pediatric patients who are asymptomatic and have no history of contact with a COVID-19 case prior to their scheduled elective surgery.

Material and Methods: This prospective study has evaluated pediatric patients who were asymptomatic and had no contact history with a COVID-19 case and who were scheduled for elective surgery between 01.05.2020-31.10.2020 in one of the world's largest pediatric hospitals. Nasopharyngeal swab (PCR) samples were obtained from all patients one day before the scheduled elective surgery.

Results: Eight hundred twelve patients in this study had a mean age of $6.98 \pm 4.37$ years. The PCR test was positive in 4 patients (0.49\%), and one patient had diarrhea during the quarantine period of 15 days.

Conclusion: The low PCR positivity rate in patients scheduled for elective surgery after a detailed history and physical examination raises the question whether elective surgery can be planned without testing. Pediatric surgeons can continue elective surgical procedures by taking precautions, but without requesting PCR, in patients who are asymptomatic and have no suspicious contact history.
\end{abstract}

Key Words: COVID-19 pandemic, Elective surgery, Pediatric patient

(1)

ERTEN EE

OZTORUN CI

ERTURK A

ERTURK

GAYHAN GI

BOSTANCI SA

DORUK H

MUFTUOGULLARIS

DEMIRS

KESKING

KESKING

AZILIMN
SENELE
0000-0002-3666-295X 0000-0002-5408-2772 $000-002-8156-5665$ : 0000-0002-8156-5665 : 0000-0001-7168-2123 0000-0002-1423-4348 0000-0002-7512-3895 :0000-0001-9711-137X 0000-0002-9295-2396 0000-0003-4720-912X 0000-0002-9990-5533 $0000-0002-5137-7209$ : $0000-002-03137-72$
Conflict of Interest / Çıkar Çatışması: On behalf of all authors, the corresponding author states that there is no conflict of interest.

Ethics Committee Approval / Etik Kurul Onayl: This study was conducted in accordance with the Helsinki Declaration Principles. Approval for this study was obtained from the Ankara City Hospital Ethics Committee and the Ministry of Health (decision number 2020-05-04T15_18_49).

Contribution of the Authors / Yazarların katkisl: ERTEN EE: Constructing the hypothesis or idea of research and/or article, Planning methodology to reach the Conclusions, Taking responsibility in the writing of the whole or important parts of the study. OZTORUN Cl: Planning methodology to reach the Conclusions, Taking responsibility in logical interpretation and conclusion of the results. ERTURK A: Organizing, supervising the course of progress and taking the responsibility of the research/study, Taking responsibility in necessary literature review for the study. DEMIR S: Organizing, supervising the course of progress and taking the responsibility of the research/study, Taking responsibility in necessary literature review for the study. SuUNEY D: Organizing, supervising the course of progress and taking the responsibility of the research/study, Taking responsibility in necessary literature review for the study. BAYHAN GI: Taking responsibility in logical interpretation and conclusion of the results. BOSTANCI SA: Organizing, supervising the course of progress and taking the responsibility of the research/study, Taking responsibility in logical interpretation and conclusion of the results. DORUK H: Taking responsibility in patient follow-up, collection of relevant biological materials, data management and reporting, execution of the experiments, Taking responsibility in logical interpretation and conclusion of the results. KESKIN G: Organizing, supervising the course of progress and taking the responsibility of the reserch/study Taking responsibility in patient follow-up, collection of relevant biological materials deta manegement and (the experiments. AZILI MN: Planning methodology to reach the Conclusions, Taking responsibility in necessary literature review for the study, Reviewing the article before submission scientifically besides spelling and grammar. SENEL E: Constructing the hypothesis or idea of research and/or article, Taking responsibility in the writing of the whole or important parts of the study, Reviewing the article before submission scientifically besides spelling and grammar.

How to cite / Atıf yazım sekli : Erten EE, Oztorun Cl, Erturk A, Guney D, Bayhan Gl, Bostanci SA, et al. Should Elective Surgical Procedures Be Delayed in Pediatric Cases in Covid-19 Pandemic? Until When? Is Pcr Required in The Preoperative Period?. Turkish J Pediatr Dis 2022;16:215-219.
Correspondence Address / Yazışma Adresi:

Elif Emel ERTEN

Ankara City Hospital, Department of Pediatric Surgery, Ankara,Turkey

E-posta: elifemelerten@hotmail.com
Received / Geliş tarihi : 05.04.2021 Accepted / Kabul tarihi : 02.07.2021 Online published Elektronik yayın tarihi

DOI: 10.12956/tchd.908015 


\section{öz}

Amaç: COVID-19 salgını, elektif cerrahiyi ertelemek de dahil olmak üzere dünya çapında sağlik hizmetlerinde büyük değişikliklere yol açtı. Bu çalışmanın amacı, planlanmış elektif cerrahi öncesinde bir COVID-19 vakasıyla temas öyküsü olmayan asemptomatik pediatrik hastalarda COVID-19 test sonuçlarıı incelemektir.

Gereç ve Yöntemler: Bu prospektif çalışma, dünyanın en büyük pediatrik hastanelerinden birinde, 01.05.2020-31.10.2020 tarihleri arasında, asemptomatik olan, COVID-19 vakasıyla temas öyküsü olmayan ve elektif cerrahi planlanan pediatrik hastaları değerlendirdi. Tüm hastalardan planlanan elektif cerrahiden bir gün önce nazofaringeal sürüntü (PCR) örnekleri alındı.

Bulgular: Bu çalışmada 847 hastanın ortalama yaşı 6.98 4.37 yıldı. PCR testi 4 hastada (\% 0.49) pozitifti ve 15 günlük karantina döneminde bir hastada ishal görüldü.

Sonuç: Ayrıntılı bir öykü ve fizik muayene sonrasında elektif cerrahi planlanan hastalarda düşük PCR pozitiflik oranı, elektif cerrahinin testsiz planlanıp planlanamayacağı sorusunu gündeme getirmektedir. Pediatrik cerrahlar asemptomatik ve temas öyküsü olmayan hastalarda önlem alarak, ancak PCR istemeden elektif cerrahi işlemlere devam edebilirler.

Anahtar Sözcükler: COVID-19 pandemi, Elektif cerrahi, Pediatrik hasta

\section{INTRODUCTION}

An infectious disease named COVID-19, caused by the SARS-CoV-2 factor, created an epidemic of acute respiratory syndrome in 2019 (1). On 11 March 2020, the World Health Organization declared COVID-19 a global pandemic, and many countries declared a state of emergency (2). This situation has profoundly affected lives and lifestyles all over the world. The articles published to date have reported that COVID-19 infection is less common in children. In the epidemiological data from China, Italy, and the USA, children diagnosed with COVID-19 constitute $1.2 \%$ to $5 \%$ of existing cases (3). Although the course of the disease in children is often asymptomatic and milder compared to adults, children are of great diagnosed COVID-19 series published in China, an examination of 2000 children showed that $13 \%$ of the cases in which the virus was found were asymptomatic(4).

As there is currently no effective treatment or vaccine available, preventing the transmission of the disease is the most important management option. For this reason, governments have taken measures such as social responsibility, mandatory use of personal protective equipment, and comprehensive regulations in health policies. In this context, the issue of postponing elective surgery has come to the fore (5). In the literature, postponing non-urgent surgical procedures has been recommended in COVID-19 patients because of higher postoperative complication rates (6). In addition, despite adherence to infection control measures, thousands of healthcare workers have been reported to be infected because of transmission from asymptomatic patients. Thus, it has been proposed to expand testing to surveillance of asymptomatic patients (7).

Our hospital served as the COVID-19 pandemic hospital for both adult and pediatric patients, and elective surgeries were halted at the onset of the pandemic. When the pandemic was partially controlled, surgeries were performed again in a controlled manner. In all emergency and elective cases requiring surgery, it became a routine practice to screen for COVID-19 before the procedure (except for cases of very urgent trauma, torsion, etc.). The purpose of this practice was to minimize the exposure of healthcare workers who intubate for general anesthesia, an aerosol-generating procedure, and to prevent transmission to other staff and patients (8).

The aim of this study was to shed light on whether elective surgeries should be restricted during the pandemic in pediatric patients who are asymptomatic and have no history of contact with a COVID-19 case and whether PCR scanning is required in the preoperative period.

\section{MATERIAL and METHODS}

Ankara City Hospital / Children's Hospital is one of the largest children's hospitals in the world, with a capacity of 720 beds. The pediatric surgery clinic in the hospital is the largest clinic in Turkey. It has 94 beds, including 66 service beds and 28 intensive care beds. In this study, asymptomatic pediatric patients aged 0-18 years who were scheduled for elective surgery between 1 May 2020 and 31 October 2020 were prospectively evaluated. The patients came to the pediatric surgery outpatient clinic one day before the scheduled elective surgery, and nasopharyngeal swab (PCR) samples were taken along with preoperative examinations. None of the patients had signs of infection such as fever, cough, runny nose, and weakness, and there was no family history of suspected COVID-19 or contact with an individual from abroad in the previous 15 days. After their examinations, the patients were put in single rooms in our inpatient services section, and no visitors were permitted except for the mother's company.

Approval for this study was obtained from the Ankara City Hospital Ethics Committee and the Ministry of Health (decision number 2020-05-04T15_18_49). Informed consent forms were signed by the parents of all patients for the study. Patients were evaluated in terms of demographic characteristics, previous surgery, and COVID-19 PCR positivity. 


\section{RESULTS}

A total of 812 patients scheduled for elective surgery, asymptomatic and without a suspicious history were included in the study. Of those patients, $76.1 \%$ (n: 618) were male and $23.9 \%$ (n: 194) were female. Their mean age was $6.98 \pm 4.37$. The operations planned for the patients and the demographics of the patients are given in table I. There were 648 (79.8\%) patients whose surgery was planned on an outpatient basis and were examined the day before and hospitalized on the morning of the surgery.

For 4 patients $(0.49 \%)$ the results of the PCR test were positive. Three of them had applied for outpatient surgery (Table II). After repeating the pediatric examinations of these 3 patients, they were sent home to complete their 15-day quarantine period. During that period, the family was asked whether the patients and those with whom they had contact had complaints such as fatigue, fever, sore throat, and diarrhea. When the quarantine period expired, the patients were called for control for elective surgery.

The other PCR positive case was a 10-day-old female patient diagnosed with rectovestibular fistula, about whom we consulted while she was in the neonatal intensive care unit. An examination was planned for the patient under general anesthesia. Although the baby's PCR test was positive, the mother's was negative. The patient was taken to the dilatation program. It was learned that operations were planned for a

Table I: Elective surgeries planned during the study period.

\begin{tabular}{lc}
\multicolumn{1}{c}{ Diagnosis, surgery } & Number of patients, \% \\
\hline Outpatient & $648(79.8)$ \\
Inguinal hernia, HL herniectomy & 256 \\
Undescended testis, orchiopexy & 99 \\
Hydrocele, hydrocelectomy & 84 \\
Phimosis, circumcision & 64 \\
Branchial cleft cyst, excision & 2 \\
Epigastric hernia, umbilical hernia, repair & 13 \\
Ankyloglossi, excision & 18 \\
Pilonidal sinus, liquid crystallized phenol application & 36 \\
Port catheter withdrawal & 32 \\
Subcutaneous lesion, excision & 25 \\
Esophageal stricture, dilatation & 19 \\
Inpatient & $164(20.2)$ \\
Torax surgery & 9 \\
Lung hydatid cyst, excision & 7 \\
Congenital diaphragmatic hernia, repair & 2 \\
Trachea-esophageal fistula, repair & \\
Abdomen surgery & 9 \\
Gastroesophageal reflux disease, fundoplication & 9 \\
Choledochal cyst, excision and Roux-en-Y hepaticojejunostomy & 5 \\
Cholelithiasis, laparoscopic cholecystectomy & 4 \\
Liver hydatid cyst, excision & 1 \\
Intestinal duplication cyst, excision & 2 \\
Hirschsprung's disease, transanal endorectal pull-through & 6 \\
Anal atresia, posterior sagittal anorectoplasty & 11 \\
Pilonidal sinus, excision & 12 \\
Diagnostic taking a rectal biopsy & 21 \\
Ostomy status, ostomy closure & 15 \\
Anal fistula, fistulotomy, fistulectomy & 12 \\
Genitourinary surgery & 32 \\
Hypospadias, urethral fistula, repair & 8 \\
Ovarian cyst, excision & \\
Examination under general anesthesia, diagnostic cystoscopy & \\
\hline
\end{tabular}

Table II: PCR positive patients.

\begin{tabular}{|c|c|c|c|}
\hline $\mathbf{n}$ & Age & Sex & Diagnosis, planned surgery \\
\hline 1 & 2 months & Male & Inguinal hernia, $\mathrm{HL}$ herniectomy \\
\hline 2 & 3 years & Female & Branchial cleft cyst, excision \\
\hline 3 & 15 years & Male & Pilonidal sinus, liquid crystallized phenol application \\
\hline 4 & 10 days & Female & Anal atresia, examination under general anesthesia \\
\hline
\end{tabular}


2-month-old with an inguinal hernia and his twin brother with whom he was in contact had diarrhea for 2 days.

\section{DISCUSSION}

Ministry of Health of Turkey has followed a rational policy since the beginning of the pandemic. During the pandemic, the recommendations of the Scientific Committee of the COVID-19 has been followed. Thus the spread of the disease was brought under control in a short time. Our elective surgeries, which were canceled at the beginning of the pandemic, were performed again in a controlled manner after the pandemic was brought under control. In the first 3 months of our study, which coincided with the initial stages of the pandemic, no patients tested positive in the elective surgeries planned patients. A low rate of positivity was found in the following 3 months. However, data about the PCR positivity rate for asymptomatic pediatric patients in Turkey is not available.

As there is no effective treatment and vaccination yet, the primary procedures to minimize the risk of transmission are avoiding close contact between individuals, frequent and effective cleaning of the environment, the availability and proper use of individual protective equipment, admitting the patient to single rooms, and following additional guidelines for symptombased screening prior to surgery (9).

However, symptom-based screening may not be sufficient because patients who may be asymptomatic can still infect others (2). Another method to reduce the risk of transmission is determine COVID-19 patients using the PCR test. It is reported that the sensitivity of the PCR test for this is about $60-70 \%$. This means that $30-40 \%$ of cases can be reported as false negatives (10).

The transmission of the disease by children, who make up a small proportion of infected patients worldwide, is controversial (11-15). Sii et al. (15) found that 40 cases (3\%) were positive from preoperative screening tests performed in 1355 asymptomatic pediatric patients scheduled for elective surgery. In the results from another study, none of the 66 asymptomatic patients younger than 18 years had PCR positivity (15).

In this study, we conducted a COVID-19 community screening by PCR test performed on children who had no infection symptoms and suspicious history and who were admitted to the hospital for elective surgery. Suspicious cases are followed up in quarantine at home, as a result of the successful work of filliation teams in our country. In cases who applied to the outpatient clinic for elective surgery, detailed symptoms and suspected COVID-19 contact questionaire were made. In symptomatic patients, surgery was delayed. However, a low PCR positivity rate was expected in patients scheduled for elective surgery. This is also a benchmark that shows the success of the fight against COVID-19. However, if a PCR test is negative, it is recommended to evaluate every patient with suspicious eyes because they can be in incubation period without clinical symptoms. PCR tests can be negative in this period (10). This brings the question up whether elective surgery can be planned without testing. Because the positivity rate of the test in patients who will undergo elective surgery was very low.

There is no clear information about how long the COVID-19 process will take. Despite the development and distribution of vaccines, uncertainty continues. However, the question of how long we can delay elective surgery raises a second important question. For example, incarceration may develop in inguinal hernias secondary to delaying, or cholecystitis may develop in cholelithiasis patients.

Eventually, we believe that until the uncertainties in the pandemic era are completely clarified worldwide, in countries that have controlled the pandemic, elective surgeries can be continued without testing PCR by taking level 2 measures (16). Because of the pandemic and the many procedures used to control it around the world, information pollution confuses not only the public but also physicians. For this reason, every physician should make a conscientious decision as a requirement of their profession, and everyone should respect it.

\section{REFERENCES}

1. Zhu N, Zhang D, Wang W, Li X, Yang B, Song J, et al. A Novel Coronavirus from Patients with Pneumonia in China, 2019. N Engl J Med 2020;382:727-33.

2. Organization WH. Novel Coronavirus (2019-nCoV) situation reports. 2020 (situation report-51). 2020.

3. Ludvigsson JF. Systematic review of COVID-19 in children shows milder cases and a better prognosis than adults. Acta Paediatr 2020;109:1088-95.

4. Wang G, Zhang Y, Zhao J, Zhang J, Jiang F. Mitigate the effects of home confinement on children during the COVID-19 outbreak. Lancet 2020;395:945-7.

5. Kennedy DM, Zambrano GJ, Wang Y, Neto OP. Modeling the effects of intervention strategies on COVID-19 transmission dynamics. J Clin Virol 2020;128:104440.

6. Surgeons ACo. COVID-19 guidelines for triage of emergency general surgery patients 2020

7. Bai Y, Yao L, Wei T, Tian F, Jin DY, Chen L, et al. Presumed Asymptomatic Carrier Transmission of COVID-19. JAMA 2020;323:1406-7.

8. Kimball A, Hatfield KM, Arons M, James A, Taylor J, Spicer K, et al. Asymptomatic and Presymptomatic SARS-CoV-2 Infections in Residents of a Long-Term Care Skilled Nursing Facility - King County, Washington, March 2020. MMWR Morb Mortal Wkly Rep 2020;69:377-81.

9. Şenel E. Child Trauma and Burn Follow up During the SARS-CoV-2 (COVID-19) Pandemic. In: Bostancı I, ed. SARS-CoV-2 in child health (COVID-19). 1. Turkey: Turkey Clinics 2020:58-61. 
10. Wang W, Xu Y, Gao R, Lu R, Han K, Wu G, et al. Detection of SARS-CoV-2 in Different Types of Clinical Specimens. JAMA 2020;323:1843-4.

11. Lopez AS, Hill M, Antezano J, Vilven D, Rutner T, Bogdanow L, et al. Transmission Dynamics of COVID-19 Outbreaks Associated with Child Care Facilities - Salt Lake City, Utah, April-July 2020. MMWR Morb Mortal Wkly Rep 2020;69:1319-23.

12. Zhu Y, Bloxham CJ, Hulme KD, Sinclair JE, Tong ZWM, Steele LE, et al. Children are unlikely to have been the primary source of household SARS-CoV-2 infections. medRxiv 2020:2020.03.26.20044826.
13. Rajmil L. Role of children in the transmission of the COVID-19 pandemic: a rapid scoping review. BMJ Paediatr Open 2020;4:e000722.

14. Geng-Ramos G, Cronin JA, Heitmiller E, Delaney M, Sandler A, Kelly SM, et al. Implementation and expansion of a preoperative COVID-19 testing process for pediatric surgical patients. Paediatr Anaesth 2020;30:952-3.

15. Sii CKS, Lee JA, Nah SA. Early experience with universal preoperative and pre-procedural screening for COVID-19 in lowrisk pediatric surgical patients requiring general anesthesia. Pediatr Surg Int 2020;36:1407-11.

16. Li Y, Zeng L, Li Z, Mao Q, Liu D, Zhang L, et al. Emergency trauma care during the outbreak of corona virus disease 2019 (COVID-19) in China. World J Emerg Surg 2020;15:33. 